The telex service, which gives the alternative of teleprinter working to speech over the telephone network, as distinct from a separate teleprinter exchange system, has also progressed. One of the latest developments of the private teleprinter services has been the introduction of broadcast systems. In these, facilities are provided and maintained, up to the limit of the number of machines at the central office, by which the renter can transmit simultaneously to any reasonable number of outstations. News agencies and police services are finding these methods very useful.

The $\mathbf{3} 8$ frequencies used by the carrier currents in the voice-frequency channels are the odd multiples of 60 cycles from 420 to 2,460 . The currents are generated by a multi-frequency machine, driven by a motor fitted with a centrifugal governor which regulates the field current and controls the speed to within \pm 0.25 per cent. Great progress has been made in standardizing 80 volts for all telegraphic purposes, and in eliminating the 24,40 and 120 volts employed for local and main-line batteries when direct current was used. The maintenance of the voice-frequency network is carried out by the ordinary repeater-station staff, who rapidly have become familiar with the new methods. The average duration of interruptions of commercial circuits due to causes which can be attributed to the voice-frequency method do not exceed five minutes per week. In the case of private wire renters, they report faults directly by telephone using the voice-frequency terminal.

It has not been found necessary to make use of sub-audio (infra-acoustic) circuits in the British Isles, except for a few cases in which submarine cables are involved. The London-Jersey duplex teleprinter circuit is one of these cases. It is in series (composited) with the Channel Islands telephone circuit consisting of a single core unloaded submarine cable. Two duplex teleprinter circuits have been installed in the continuously loaded submarine telephone cable between Blackpool and Port Erin (Isle of Man). These circuits are noteworthy as they use only seven volts for transmission so as to avoid the risk of affecting the loading material used in the cable. Neglect of this gives rise to 'cross-talk' due to minute changes in the inductance.

The difficulties experienced at first in maintaining teleprinter speeds constant have been overcome, The difference in the speeds now seldom exceeds one per cent. The speed is checked by means of stroboscopes and synchroscopes. The latter instruments have been found to be much the more accurate. In the case of telephony, voice-frequency signalling methods and improvements in transmission technique have led to development in the direction of extending the automatic system to include the trunk circuits. This avoids the delays and costs of intermediate operating. Similarly in telegraphy, the elimination of probably 50 per cent of the operating transactions and delays would be possible by means of through automatic switching from the sending to the receiving office. The present voice-frequency network makes a framework for such a scheme which would have been quite impracticable under the old physical line conditions.

Telegraphy is now in a position to share in the rapid advances recently made in the telephone field. The teleprinter with its typewriter keyboard, the elimination of the distance factor by voice-frequency methods and the cheaper private wire telegraphic rentals should prove a boon to the commercial world.

\section{Humboldt's Plan in 1836 for a World Magnetic Survey}

4 ARLY in 1836 Alexander von Humboldt sent a 1etter to the Duke of Sussex, as president of the Royal Society, inviting the co-operation of the Society in the organization of a world magnetic survey. The letter was referred to Christie and Airy, whose report was read to the Royal Society on November 24, 1836. As von Humboldt's suggestions had a great influence on the steps afterwards taken, a few extracts from the report are given here :

"In this letter," said Christie and Airy, "M. de Humboldt developes a plan for the observation of the Phenomena of Terrestrial Magnetism worthy of the great and philosophic mind whence it has emanated and one from which may be anticipated the establishment of the theory of these phenomena. . . The Baron de Humboldt and MM. Arago and H. Kupffer having, by the co-operation of many zealous observers, succeeded in establishing permanent magnetic stations extending from Paris to China, M. de Humboldt solicits, through His Royal Highness the President, the powerful influence of the Royal Society in extending the plan by the estab. lishment of new stations. The plan which he proposes ... is that magnetical observations, whether of the direction of the horizontal and inclined needles, or for the determination of the variations of the magnetic force, should be made simultaneously at all stations, at short intervals of time, for a certain number of hours and at fixed periods of the year precisely similar to the plan which has been recom. mended and adopted by Sir John Herschel with reference to observations of the barometer and thermometer." He also "considers that it deeply interests the advancement of mathematical and physical sciences that, under the auspices of His Royal Highness the President, the Royal Society should exert its influence in extending the line of simultaneous observations, and in establishing permanent magnetic stations in the tropical regions on both sides of the equator, in high southern latitudes and in Canada. . . . Should the proposition meet with their concurrence he begs that the Royal Society will enter into direct communication with the Royal Society of Göttingen, the Royal Institute of France and the Imperial Academy of Russia, to adopt the most proper measures to combine what is proposed to be established with what already exists".

After a full review of the subject, Christie and Airy went on to say, "By referring to M. de Humboldt's letter, it will be seen that the plan of observation so comprehensively conceived by him, has been most powerfully and liberally patronized by the Governments of France, of Prussia, of Hanover, of Denmark and of Russia ; indeed it is quite manifest that a plan so extensive in its nature must be far beyond the means of individuals, and even of scientific societies, unaided by the governments under which they flourish. . . . To suppose . . . that the Government of this, the first maritime and commercial nation of the globe, should hesitate to patronize such an undertaking ... would imply that our Government is not alive either to the interests or to the scientific character of the country, and would show that we had little attended to the history, even in our own time, of scientific research, which has been so liberally promoted by the Government. . . We therefore feel assured that, when 
it shall have been represented to the Government that the plan of observation advocated by the Baron de Humboldt is eminently calculated to advance our knowledge of the laws which govern some of the most interesting phenomena in physical science... that the patronage to the undertaking which is so essential to its prosecution will be most readily accorded. . . ."

\section{Educational Topics and Events}

CAmbridge.-M. Krook, research student of Gonville and Caius College, has been elected to an Isaac Newton studentship, and E. N. Rowland, of Gonville and Caius College, to an additional Isaac Newton studentship.

Prof. W. V. D. Hodge, Lowndean professor of astronomy and geometry, has been elected into a non-stipendiary fellowship at Pembroke College.

GLASGow.-Dr. William Marshall Smart, chief assistant in the Observatory and lecturer in mathematics in the University of Cambridge, has been appointed regius professor of astronomy, in succession to Prof. Ludwig Becker, who has resigned.

Mr. Oliver Shewell Franks, fellow and prælector in philosophy of Queen's College, Oxford, has been elected to the chair of moral philosophy rendered vacant by the death of Prof. A. A. Bowman.

Dr. John Dougall has been appointed Gibson lecturer in the history of mathematics.

Sir Frederick Crombie Gardiner has given $£ 10,000$, and the trustees of his brother, the late Mr. William G. Gardiner, of Moraig, Stirling, have also allocated $£ 10,000$ to the University, towards the provision of a new Medical Institute to be erected in connexion with the Western Infirmary. This is to be known as the "Gardiner Medical Institute" and will be at the disposal of the regius professor of medicine for the purpose of teaching and research.

In a recent address to the General Council of the University, the new Principal, Sir Hector Hetherington, mentioned that during the last six years, whereas $£ 130,000$ has been received for scholarships, only $£ 47,000$ has been received for general expenditure on lands, buildings, equipment, etc. He pointed out that, at present, aid to the University is more important and beneficial than the provision of additional scholarships.

Londox.-The following degrees have been conferred : D.Sc. in chemistry on E. E. Jelley, for published works on chemical microseopy and photographic chemistry ; D.Sc. (engineering) on R. W. Bailey, for published works on creep and stress in metals, etc.

OxForD.-Dr. Simon Flexner, director of the Rockefeller Institute for Medical Research, has been appointed George Eastman visiting professor for the academic year 1937-38.

Prof. R. V. Southwell has been elected a member of Hebdomadal Council.

Lord Nuffield has been elected an honorary fellow of Pembroke College.

Dr. F. Simon, of Balliol College, has been appointed University reader in thermodynamies for five years from October 1 .

It is proposed to confer the honorary degree of D.Sc. early next year on Dr. J. D. Pollock, chairman of the Metal Industries Company and of the British Oxygen Company, and a Carnegie Trustee.
Sheffield.-Prof. F. C. Lea, formerly professor of mechanical engineering, and Prof. J. Husband, formerly professor of civil engineering, have been given the title of emeritus professor.

The following appointments have recently been made : Dr. K. Mellanby, Sorby fellow, as honorary lecturer in zoology; Mrs. H. Mellanby, as honorary research assistant in the Department of Zoology; Mr. J. E. Stanworth and Mr. F. R. Harris, as research fellows in the Department of Glass Technology.

Dr. J. C. Paisley has resigned his post of junior assistant bacteriologist.

A Number of Commonwealth Research Fellowships, tenable by British subjects at certain American universities, are offered for award in 1937 by the Commonwealth Fund of New York. Twenty-four Ordinary Fellowships are offered to candidates living in Great Britain or Northern Ireland who are graduates of a university therein. Two Dominion Fellowships are available to British candidates living in a British Dominion or Colony who are graduates of a Colonial university. There are also five Service Fellowships tenable by British candidates holding appointments overseas under the British Government or a British Colonial Government, and three Home Civil Service Fellowships tenable by candidates hold. ing appointments in the Home Civil Service. The Fellowships are tenable for two years, and are not open to women. Further information can be obtained from the Secretary, Commonwealth Fund Fellowships, 35 Portman Square, London, W.1.

"AN Educational Platform for 1936", formulated at Stanford University, California, last July by the Dean of the School of Education as a result of a conference held there on "Curriculum and Guidance", has been published in School and Society (Sept. 5). It is a fairly comprehensive reasoned statement of principles, aims and aspirations, and is valuable as an indication of some trends of thought in academic circles in the western States of America. The impact of the recent rapid advances in technological science on a society unprepared to readjust its institutions, which are consequently "jarred to their very foundations", calls for a concentration of effort on the part of educators to fit the younger generation and, so far as possible, the community at large, to take part in the social advances indispensable for the preservation of a democratic State. Hence the educational programme must stress the study of present conditions and the potentialities of the future, the study of the past being ancillary thereto, and the teacher's position shifting from that of merely transmitting information about things which have been done to one of dynamic influence in social evolution. Associated with this is the development of what is referred to as "the guidance service" to aid the student in defining his goals - vocational, social-civic, recreational and health. But guidance should imply more than mere counsel. The 'platform' envisages school education as an apprenticeship for worthy adult life, including the actual doing under supervision of things which constitute desirable living. This implies provision for participation in many varied activities outside courses of formal study. The last item in the proposals calls for a thorough-going broadening and raising of the standards of teacher-training institu. tions. 